\title{
The Good Society: Defining And Measuring Wellbeing Between Complexity And Limit ${ }^{2}$
}

Filomena Maggino ${ }^{1}$

Tipo de trabajo: Artículo

Material original autorizado para su primera publicación en el Journal de Ciencias Sociales de la Facultad de Ciencias Sociales de la Universidad de Palermo

Recibido 7-9-2012

Aceptado 1-10-2012

\section{La Buena sociedad: definiendo y midiendo el bienestar, entre la complejidad y el límite}

\section{Resumen}

Investigadores de todo el mundo han dedicado años y se encuentran trabajando activamente en la definición de conceptos y medidas acerca del bienestar. En algunos casos el debate se simplificó a partir de la pregunta si un indicador podía reemplazar al PBI. En este sentido y para definir que es una "Buena sociedad" (Good society) es necesario tener en cuenta dos conceptos: complejidad y limite. El debate en relación a esta definición data de Aristoteles y resultaría imposible poder revisar todas las definiciones que se han intentado. En este artículo se intenta proveer una interpretación acerca de los instrumentos que se han utilizado a fin de ayudar a la diferenciación entre las propuestas emergentes serías y las meramente propagandísticas.

Palabras clave: Medición- Bienestar-Indicadores-Buena sociedad

\begin{abstract}
Recently, the debate on new measures of wellbeing reached a wide audience especially thanks to the big media's "ballyhoo". That debate, very often accompanied by Robert Kennedy's word (March 18,1968 , speech at Kansas University) has been urged also thanks to many prestigious initiatives, like the commission appointed by French President in 2008 and now known through the chairs' names (Stiglitz, Sen e Fitoussi). What is never said is that since many years, many researchers all over the world are continuously working on defining concepts and measures of wellbeing. Looking at this movement's outputs allows us to realize that what is reasserted by the last initiatives can be considered, in many respects, neither really original nor avant-garde (Maggino \& Ruviglioni, 2010). In many cases, the debate has been trivialized to the simple concern "what indicator can replace GDP?" As we will see, actually defining what a good society is, and consequently its observation and monitoring, should take into account two important and interrelated concepts: complexity and limit.

\footnotetext{
${ }^{1}$ Doctora en Estadística Social. Profesora de la Universitá degli studi di Firenze (Italia). Presidenta de la International Society for Quality of Life Studies (ISQOLS). Presidenta de la Associazione Italiana per gli studi sulla Qualità della Vita (AIQUAV) y miembro del Comité Científico para la medición del bienestar CNEL/ISTAT (Italia).

filomena.maggino@unifi.it
}

2 Acknowledgement: the publication has been possible also thanks to the project KRF or NRF-2013S1A3A2054622 (Korean National Research Foundation) 
Concepts of good society: classification attempts. During the history of political philosophy, since Aristotle, the conceptual approaches trying to define what is good society were and are many. It is quite impossible to examine all those definitions and this work has no intention to do that exhaustively. This work aims at providing anyone with interpretative instruments allowing us to orient ourselves among all the emerging proposals and to distinguish between serious and propagandistic ones.

Key words: Measure-Wellbeing- Indicators- Good Society

\section{Good society declined in terms of "structures of values"}

According to this criterion, the distinction between different definitions can be explained by the different structures of life values adopted. In this sense, three different philosophical approaches can be identified (Diener \& Suh, 1997), synthesized in the following table:

\begin{tabular}{|c|c|c|c|c|}
\hline \multirow{2}{*}{$\begin{array}{c}\text { What is societal } \\
\text { wellbeing related } \\
\text { to? }\end{array}$} & \multirow{2}{*}{$\begin{array}{l}\text { What should be } \\
\text { observed }\end{array}$} & \multicolumn{2}{|c|}{ Observational strategies? } & \multirow{2}{*}{$\begin{array}{l}\text { What } \\
\text { measures? }\end{array}$} \\
\hline & & What? & At what level? & \\
\hline $\begin{array}{l}\text { Functioning and } \\
\text { capability } \\
\text { to select goods } \\
\text { and services } \\
\text { that one desires }\end{array}$ & $\begin{array}{c}\text { Income, } \\
\text { considered the main } \\
\text { mean } \\
\text { to achieve an acceptable } \\
\text { standard of living }\end{array}$ & $\begin{array}{c}\text { Wealth } \\
\text { (observed } \\
\text { or } \\
\text { estimated) }\end{array}$ & $\begin{array}{l}\text { - individual (micro) } \\
\quad \rightarrow \text { income } \\
\text { - c o m m u n i t y } \\
\quad \text { (macro) } \rightarrow \text { GDP }\end{array}$ & $\begin{array}{l}\text { Economic } \\
\text { indices }\end{array}$ \\
\hline Normative ideals & $\begin{array}{c}\text { Set of characteristics } \\
\text { inspired by normative } \\
\text { aims, } \\
\text { grounded in moral } \\
\text { values } \\
\text { or policy goals }\end{array}$ & $\begin{array}{l}\text { Living } \\
\text { conditions }\end{array}$ & $\begin{array}{l}\text { - individual (micro) } \\
\quad \rightarrow \text { work, ... } \\
\text { - community } \\
\quad \text { (macro) } \rightarrow \\
\text { social cohesion, } \\
\text { democracy }\end{array}$ & $\begin{array}{l}\text { Social } \\
\text { indicators }\end{array}$ \\
\hline $\begin{array}{l}\text { Subjective } \\
\text { experiences }\end{array}$ & $\begin{array}{c}\text { Individual's } \\
\text { cognitive and affective } \\
\text { reactions to } \\
\text { one's own life } \\
\text { (or specific domains) }\end{array}$ & $\begin{array}{c}\text { Subjective } \\
\text { perceptions } \\
\text { and } \\
\text { attitudes }\end{array}$ & $\begin{array}{l}\text { Individuale (micro) } \\
\rightarrow \text { satisfaction }\end{array}$ & $\begin{array}{l}\text { Subjective } \\
\text { indicators }\end{array}$ \\
\hline
\end{tabular}

\section{Good society declined in terms of different observational perspectives}

According to this criterion, the different conceptual approaches refer to one of the following perspectives: 


\begin{tabular}{|c|c|}
\hline $\begin{array}{l}P \\
R \\
\mathbf{O} \\
\mathbf{C} \\
\mathrm{E} \\
\mathbf{S} \\
\mathbf{S}\end{array}$ & $\begin{array}{l}\text { Societal wellbeing is seen as a function of concepts like: } \\
\text { - development (often referring to qualitative dynamic change of } \\
\text { an economic system) } \\
\text { - growth (referring to quantitative expansion on the scale of } \\
\text { physical dimensions of economic system). } \\
\text { Both concepts refer to different but interactive components (economic, } \\
\text { structural and technologic) that should be considered together (Horn, } \\
\text { 1993). } \\
\text { A term that could unify the previous ones is progress, indicating } \\
\text { generally "moving forward" (from Latin "progressus", going forward, } \\
\text { advance). As limits or potentialities of the process delined in terms of } \\
\text { "moving forward" is reached, the attention could be turned towards the } \\
\text { reverse and opposite process, "de-development", de-growth, recession, } \\
\text { (. (Horn, 1993). } \\
\text { This approach assumes that a (more or less virtuous) process of } \\
\text { economic growth leads almost automatically to individual and collective } \\
\text { well-being. }\end{array}$ \\
\hline & $\begin{array}{l}\text { Societal wellbeing is seen as a function of concepts like: } \\
\text { - availability of economic resources (manpower, equipment, } \\
\text { budget), } \\
\text { - income and wealth distribution (and its social implications), } \\
\text { - } \text { national welfare and its relationships and impacts on economics. } \\
\text { - identifies oneself in his/her own community } \\
\text { - } \quad \text { acquires collectively the knowledge, values and skills to so that to } \\
\text { share and expand the community's resources for the benefit of all its } \\
\text { members without being at the expense of other communities or of the } \\
\text { environment (Horn, 1993). In other terms, the conditions should be } \\
\text { sustainable. }\end{array}$ \\
\hline $\begin{array}{l}\text { G } \\
\mathbf{O} \\
\text { A } \\
\text { L } \\
\text { S }\end{array}$ & $\begin{array}{l}\text { This perspective moves the attention from the process (development, } \\
\text { progress, growth) to the goal: } \\
\text { - } \text { sustainability, } \\
\text { - quality of life, } \\
\text { - wellbeing, } \\
\text { - } \text { and so on. }\end{array}$ \\
\hline
\end{tabular}

Good society seen in terms of points of observation

According to this criterion (Berger-Schmitt \& Noll, 2000), the different conceptual approaches are distinguished with reference to the point of observation, which can be centred on:

- $\quad$ the individual dimension (quality of life);

- the community dimension (quality of societies).

The table presented in Annex A synthesises the classification. 


\section{Good society is declined in terms of different theoretical views of Quality-of-Life}

According to this criterion (Sirgy, 2011), the different conceptual approaches to good society are distinguished with reference to the different theoretical perspectives through which Quality of Life is seen:

\section{(a) Socio-economic development}

According to this approach, social development follows the achievement of a satisfactory level of economic development. This concept has been revised. Two emergent concepts are related to

- Capital: in particular, there are five major sources of community capital: (a) financial or economic capital, (b) human capital, (c) social capital, (d) built capital, and (e) natural capital. Particular attention has been dedicated to the social capital dimension, seen as more significantly related to subjective well-being than economic indicators.

- Stocks and flows: as known, stocks constitute capital account whereas flows make up the current account. These concepts have been translating also into psychological terms: stocks are the strength of one's personality, health, social networks, leisure skills and equipment, work skills and equipment, education and general knowledge, and socioeconomic status. Flows are satisfaction or dissatisfaction experienced in relation to daily activities in the context of various life domains (finances, leisure, family, job, friendships, and health). Thus, a person characterized as having a high QOL is likely to possess good stocks and experiences good flows.

Even though there is enough evidence to support the notion that economic development is strongly related to social development (i.e., economic development is highly correlated with community indicators of health, high quality government institutions, environmental pollution, and subjective well being), the concept of socio-economic development is not able to capture the entire domain of the QOL construct, since it leaves out other important dimensions of well-being such as social well-being, health well-being, and environmental well-being.

\section{Personal utility}

According to this approach, quality of life is related to the subjective experience of individuals, observed in terms of evaluations, perceptions, and expressions of satisfaction of their living conditions. The numerous conceptual models classified with reference to how subjective well-being is explained. The explanations can be related to individual's

(i) personality traits (top-down approach);

(ii) evaluations and values (bottom-up approach, comparison approach, multiple-discrepancy approach, purpose and meaning in life);

(iii) feelings and emotions (hedonic psychology approach, positive/negative affect, positive emotions theory) 
(iv) perceptions and functionings (flow and engagement approach, eudaimonistic identity theory) (v) mixed approach (moods-and-disposition approach, cognitive-and-affective components approach, up-down approach).

\section{Just society}

According to this approach, the quality of life of a community is that in which its members enjoy a high level of social justice, when two distinct principles are met:

1) equality in the assignment of basic rights and duties, which can be viewed in terms of at least six dimensions: (i) right to meet basic needs, (ii) right to safety, (iii) right to employment, (iv) right to a healthful environment, ( $v$ ) duty to pay taxes, and (vi) duty to vote.

2) inequalities are justified to benefit the least advantaged members of the society (children, women, minorities, the poor, the disabled).

\section{Human development}

Quality of Life is related to human need satisfaction (satisfaction of people's developmental needs). Developmental needs refer to a hierarchy of

- lower-order needs such as health, safety, and economic needs (lower-order needs); generally, they can be viewed in terms of nine dimensions: (a) environmental pollution, (b) disease incidence, (c) crime, (d) housing, (e) unemployment, (f) poverty and homelessness, (g) cost of living, (h) community infrastructure, (i) illiteracy and lack of job skills.

- higher-order needs such as social, esteem, actualization, knowledge, and aesthetics needs; generally, they can be seen in terms of nine different dimensions: (a) work productivity and income, (b) consumption of non-basic goods and services, (c) leisure and recreational activities, (d) educational attainment, (e) community landscape, (f) population density and crowdedness, (g) arts and cultural activities, (h) intellectual activities, and (i) religious activities.

To achieve a high level of quality of life, community members have to satisfy both lower- and higher-order developmental needs.

\section{Sustainability}

Sustainability has been defined by the World Commission on Environment and Development as the effort to meet the needs of the present without compromising the ability of future generations to meet their own needs. Two different perspectives of sustainability can be seen:

- environmental sustainability (environmental wellbeing)

- environmental and human sustainability (sustainable community, sustainable development, and sustainable growth) by considering sustainability in terms of the interrelationship between the human and environmental dimensions. 
- "sustainable communities" are those that enhance the economic, environmental, and social characteristics of a community. The three sets of QOL characteristics (economic, environmental, and social) are also referred to as "three E's of Sustainability" (economy, environment, equity).

- "sustainable development" is a combination of human well-being and environmental well-being. Since, there is no good human condition in a bad environment, indicators of human wellbeing should include also indicators concerning environmental well-being.

\section{Functionings}

Individual life is a combination of doings and beings - referred to as functionings (activities and situations that people consider as important in their lives, e.g., health status, level of education, and current employment status). Quality of life is assessed with reference to the individual freedom to choose among the various functionings. This freedom to choose is referred to as capabilities, defined as the ability to achieve functionings. In other words, functionings represent the goals of human living, with the capability indicating the freedom or choice that one has to experience the end results of functionings. From a functionings' perspective well-being can be developed in terms of a summary index of people's functionings. E.g., education provides freedom to earn a living and pursue a desired lifestyle. Thus, the desired lifestyle can be viewed as the outcome or functioning, whereas education is the means for achieving it (i.e., capability). Many health-related indicators projects are now using the concept of functioning to guide their indicators efforts.

\section{Good society and complexity: towards a comprehensive definition}

From the previous synthesis it is easily deducible that each of the identified approaches is not able to fully describe what can be defined good society. In fact, they focus upon some aspects and do not consider the reality in its complexity.

In order to overcome partialities and incompleteness, the adopted conceptual framework should define and allow the complexity to be read, a multidimensional and comprehensive definition able to conciliate micro (individual) and macro (societal) level.

A possible multidimensional conceptual definition could be the following: a good and healthy society is that in which each individual has the possibility to

- participate to the community life,

- develop skills, abilities, capabilities and independency,

- adequately choose and control his/her own life,

- be treated with respect in a healthy and safe environment and by respecting the opportunities of future generations.

This definition points out the individual's wellbeing (quality of life) and its equitable distribution (economic and social cohesion) and their limits in environmental and time perspective (sustainability).

From definition to monitoring

Assessing quality of life and its equity and sustainability needs social and political consensus 
not only on the concepts (quality of life, equity and sustainability) but also on three key topics (Noll, 2004):

1. Thematic areas considered relevant (domains/ambits). The thematic areas refer to the individual, family, territorial, societal ambits in which each individual lives. Actually, a shared list of ambits showing explicit priority does not exist, also because the list strictly depends on value judgments, valid and acceptable in a certain place or time. However, many scholars noticed that many ambits recur in empirical studies (Felce \& Perry, 1995; Nuvolati, 1997; Johansson, 2002; Stiglitz et al., 2009), highlighting how human conditions lead individuals to face challenges that are common all over the world and that require collective solutions ${ }^{2}$. Generally, the differences concern the importance assigned to each domain.

2. Good and bad living conditions to be identified (criteria). For each ambit, the related variables should be defined and the corresponding indicators should be identified. The consensus on what variables and what indicators and on their interpretation is lower. What it should be clarified is that comparing different realities (represented by countries or by areas inside one country) does not necessarily imply using the same variables and - consequently - the same indicators but requires differentiated choices (Stiglitz et al., 2009). In fact, variables' choice depends on shared societal values, which are functions of time and place. Consequently, transferring a quality-of-life concept developed in a certain context could be misleading.

3. Direction to be adopted by the society (goals). Goals are not only time and space dependent but rely on political views. In this perspective, the role that international organizations can play is definitely important in defining the goals to be pursued.

A particular path has to be followed in order to measure and monitor country wellbeing and progress, leading from concept to measure, to syntheses, to interpretation. In order to achieve the possibility to monitor a country consistently with the definition of progress and wellbeing, the following definitions are needed: (a) the concepts to be measured and monitored and their conceptual dimensions, (b) the ambits (domains) in which the concepts are observed and monitored, (c) the indicators to be developed and constructed (including their synthesis and the perspectives through which the indicators should be observed and the consistent organization of the monitoring process), and (d) interpretative / explanatory models, which actually link obtained results to the previously defined concept.

\section{The concepts and their dimensions}

The previous definition requires an articulated, structured and consistently complex observation of the reality, involving three concepts (Berger-Schmitt \& Noll, 2000):

\footnotetext{
${ }^{2}$ According to Johansson (2002), human beings, in order to fulfil themselves, need

"To be cared for, nurtured and fostered as baby

To be trained or educated as a preparation for the adult roles

To find a job in the system of production

To find one's own place to live and to form a family

To maintain health over the whole life cycle

To be protected against violence and crime

To find a societal identity in culture and as a citizen".
} 
(i) quality of life à individual (micro) level

(ii) economic and social cohesion à community (macro) level

(iii) sustainability à relationship between the two previous levels, the environment and the future

\section{Quality of life (individual level)}

Recently, a large number of people expatiate upon quality of life, considered one of the main objectives to be pursued in order to obtain a healthy society. Unfortunately, as often as not, at academic level but not only, this concept has been trivialized by reducing it (or making it dovetail with) a simple subjective expression; that is typically done by who identifies quality of life with happiness, which is considered, in other approaches, related to personality traits. Actually, the concept of quality of life is more complex and, in other words, multidimensional. Wolfgang Zapf $(1975,1984)$ proposed a quality-of-life model with two main dimensions:

- living conditions:

Outcomes

resources and capabilities

external circumstances

subjective evaluations
- subjective wellbeing: cognitive and affective components, positive and negative components.

Many aspects are involved, like perceptions, attitudes, evaluations, satisfaction and subjective wellbeing expressions, and so on and could be related to different life domains.

\section{Economic and social cohesion (community level)}

Two different dimensions can be identified in order to define economic and social cohesion, respectively negative and positive:

- social exclusion, referring mainly to welfare distribution

inequalities among individuals, groups, societies (women and men, generations, social strata, disabled, races, citizenship groups, ...),

regional disparities;

\section{- social inclusion / integration of individuals, groups and societies}

social and political activities and engagements (associations, organizations, ...),

quality of relations (e.g., shared values, conflicts, solidarity),

social relations (informal networks),

trust in institutions.

\section{Sustainability}

An important additional concept comes into the picture is represented by the relationship between the previous two conceptual dimensions and the limit in their development and promotion with reference to the time and space perspective. Actually, the idea of limit can be seen as related to 
the concept of sustainability. ${ }^{3}$ Sustainability can be defined by referring to the capitals which should be preserved (five dimensions) and two perspectives:

\begin{tabular}{|c|c|c|c|c|}
\hline & & & Present generations' ... & Future generations' ... \\
\hline \multirow{5}{*}{ 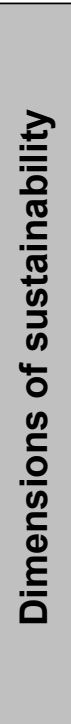 } & physical & $\begin{array}{l}\text { individual } \\
\text { level }\end{array}$ & \multicolumn{2}{|c|}{...behaviours affecting individual health } \\
\hline & social & $\begin{array}{l}\text { individual } \\
\text { and } \\
\text { community } \\
\text { level }\end{array}$ & \multicolumn{2}{|c|}{...behaviours affecting social relations and networks } \\
\hline & economic & $\begin{array}{l}\text { individual } \\
\text { and } \\
\text { community } \\
\text { level }\end{array}$ & \multicolumn{2}{|c|}{...processes affecting welfare } \\
\hline & human & $\begin{array}{l}\text { individual } \\
\text { level }\end{array}$ & \multicolumn{2}{|c|}{$\begin{array}{l}\text {...processes affecting individual skills, training, } \\
\text { education, heath }\end{array}$} \\
\hline & natural & $\begin{array}{l}\text { community } \\
\text { level }\end{array}$ & \multicolumn{2}{|c|}{...processes affecting natural resources } \\
\hline & & & \multicolumn{2}{|c|}{ Perspectives of sustainability } \\
\hline
\end{tabular}

An additional (contextual) dimension: the socio-economic structure

Besides the defined concepts, an additional dimension allowing the description of the whole society should be identified: the socio-economic structure, articulated in (i) demographic and socio-economic structures, and (ii) values and attitudes.

The ambits to be monitored

The relevant concepts and their dimensions have to be assessed and observed within each life domain (ambit) life domains represent segments of the reality in which fundamental concepts should be observed and monitored. They typically are:

$\begin{array}{ll}1 & \text { households and families } \\ 2 & \text { Housing } \\ 3 & \text { Transport } \\ 4 & \text { leisure and culture } \\ 5 & \text { Participation } \\ 6 & \text { education } \\ 7 & \text { labour market/working condition } \\ 8 & \text { Income and standard of living } \\ 9 & \text { Health } \\ 10 & \text { Environment } \\ 11 & \text { social security } \\ 12 & \text { crime and safety } \\ 13 & \text { total life situation }\end{array}$

\footnotetext{
3 "Time" could represent an example: any attempt aimed at improving connections between cities (in terms of travelling time) should face a limit. Time spent to go from one city to another can be reduced thanks to new technologies and improvements of territorial structures. However technology could be improved, the time reduction's amount would be shorter and shorter, while the price in terms of eroded capitals could improve more and more.
} 


\section{The definition / selection of indicators}

The indicators represent the observable elements to be defined for each conceptual dimension and each ambit/domain.

This process leads to the composition of a [conceptual] matrix, which for its characteristics and possible application can be defined monitoring matrix.

\begin{tabular}{|c|c|c|c|c|c|c|c|c|c|c|c|c|c|c|}
\hline \multirow[t]{2}{*}{$\begin{array}{c}\text { CONCEPTS } \\
\downarrow\end{array}$} & \multirow[t]{2}{*}{$\begin{array}{c}\text { DIMENSIONS } \\
\downarrow\end{array}$} & \multicolumn{13}{|c|}{$\begin{array}{c}\text { LIFE DOMAINS (AMBITS) } \\
\downarrow\end{array}$} \\
\hline & & 1 & 2 & 3 & 4 & 5 & 6 & 7 & 8 & 9 & 10 & 11 & 12 & 13 \\
\hline \multirow{2}{*}{ Quality of life } & $\begin{array}{l}\text { Living } \\
\text { conditions }\end{array}$ & & & & & & & & & & & & & \\
\hline & $\begin{array}{l}\text { Subjective } \\
\text { wellbeing }\end{array}$ & & & & & & & & & & & & & \\
\hline \multirow{2}{*}{$\begin{array}{l}\text { Economic } \\
\text { and social } \\
\text { cohesion }\end{array}$} & $\begin{array}{l}\text { Disparities, } \\
\text { inequalities } \\
\text { and social } \\
\text { exclusion }\end{array}$ & & & & & & & & & & & & & \\
\hline & $\begin{array}{l}\text { Social } \\
\text { relations and } \\
\text { ties (social } \\
\text { capital) }\end{array}$ & & & & & & & & & & & & & \\
\hline \multirow{3}{*}{ Sustainability } & Human capital & & & & & & & & & & & & & \\
\hline & Natural capital & & & & & & & & & & & & & \\
\hline & $\ldots$ & & & & & & & & & & & & & \\
\hline \multirow{2}{*}{$\begin{array}{l}\text { Socio- } \\
\text { economic } \\
\text { structure }\end{array}$} & $\begin{array}{l}\text { Demographic } \\
\text { and socio- } \\
\text { economic } \\
\text { structures }\end{array}$ & & & & & & & & & & & & & \\
\hline & $\begin{array}{l}\text { Values and } \\
\text { attitudes }\end{array}$ & & & & & & & & & & & & & \\
\hline
\end{tabular}

In that matrix, not each combination of conceptual dimension and ambit (à cell) will be covered by indicators.

\section{Perspectives and organization of the monitoring process}

In order to respect the complexity of reality, through a comprehensive approach, developing and constructing quality-of-life indicators should take into account different monitoring perspectives. Each perspective requires a particular monitoring organization and allows comparisons made for - the same reality across time (years, months, ...) à time perspective. This perspective requires an organization in term of cadence (rate) and continuity through which indicators are collected 
and updated; indicators will not have the same rate but will be updated with reference to the permanence of the measured phenomenon;

the same dimensions between areas (regions, provinces, ...) à territorial perspective. This perspective requires an organization in terms of size of the monitored area; the size is related to the institutional/organizational level which the decisional system (policy) is sized on. National level is certainly the most relevant. It should be taken into account that observing a wide territory does not entail that a lower level is necessarily covered. Beyond statistical representativeness, the conceptual model (in terms of dimensions and/or indicators) and the observation approach need to be reviewed and adapted in order to monitor the lower level (e.g., province, city, ...). Consequently, the approach aimed at reaching smallest area estimations from representative data collected in wider areas appears questionable. Projects calibrated on smallest areas should be urged and encouraged.

the time between groups (genders, generations, ...) à group perspective. This perspective requires an organization in terms of sample of observed individuals.

From the analytical point of view, the perspectives can be combined.

The perspectives help in understanding the relationship between the concepts and the different components, in order to understand what ambits can be related to policy actions (system analysis).

\section{Indicators' selection}

Different issues need to be addressed in order to selecting and managing indicators, especially when this is carried out into a complex system allowing the accomplishment of functions like monitoring, reporting and accounting. Michalos (in Sirgy et al., 2006) identified 15 different issues related to the combination of social, economic and environmental indicators. As Michalos asserts, the issues collectively yield over 200,000 possible combinations representing at least that many different kinds of systems (Sirgy et al., 2006):

- Settlement/aggregation area sizes: e.g., the best size to understand air pollution may be different from the best size to understand crime.

- Time frames: e.g., the optimal duration to understand resource depletion may be different from the optimal duration to understand the impact of sanitation changes.

- Population composition: e.g., analyses by language, sex, age, education, ethnic background, income, etc. may reveal or conceal different things.

- Domains of life composition: e.g., different domains like health, job, family life, housing, etc. give different views and suggest different agendas for action.

- Objective versus subjective indicators: e.g., relatively subjective appraisals of housing and neighbourhoods by actual dwellers may be very different from relatively objective appraisals by "experts".

- Positive versus negative indicators: negative indicators seem to be easier to craft for some domains, which may create a biased assessment, e.g., in the health domain measures of morbidity and mortality may crowd out positive measures of well-being.

- Input versus output indicators: e.g., expenditures on teachers and school facilities may give a very 
different view of the quality of an education system from that based on student performance on standardized tests.

- Benefits and costs: different measures of value or worth yield different overall evaluations as well as different evaluations for different people, e.g., the market value of child care is far below the personal, social or human value of having children well cared for.

- Measurement scales: e.g., different measures of well-being provide different views of people's well-being and relate differently to other measures.

- Report writers: e.g., different stakeholders often have very different views about what is important to monitor and how to evaluate whatever is monitored.

- Report readers: e.g., different target audiences need different reporting media and/or formats.

- Conceptual model: e.g., once indicators are selected, they must be combined or aggregated somehow in order to get a coherent story or view.

- Distributions: e.g., because average figures can conceal extraordinary and perhaps unacceptable variation, choices must be made about appropriate representations of distributions.

- Distance impacts: e.g., people living in one place may access facilities (hospitals, schools, theatres, museums, libraries) in many other places at varying distances from their place of residence.

- Causal relations: before intervention, one must know what causes what, which requires relatively mainstream scientific research, which may not be available yet.

Choices and options selected for each issue have implications for the other issues. The issues are not mutually exclusive and are not expected to be exhaustive as other can be identified.

Dealing with these issues is merely a technical problem to be solved by statisticians or information scientists. On the other side, the construction of indicators of well-being and quality of life is essentially a political and philosophical exercise, and its ultimate success or failure depends on the negotiations involved in creating and disseminating the indicators, or the reports or accounts that use those indicators. (Michalos, in Sirgy et al., 2006)

Within a system, we consider also the difficulties related to the availability of indicators (across time and space) and in harmonizing different data sources and levels of observation.

\section{Quality of indicators}

Many international institutions, like World Bank \& Unesco (Patel et al., 2003) and Eurostat (2000) tried to identify the attributes of quality that indicators (and approaches aimed at their management) should possess and need to be considered in the process of developing of new indicators or of selecting available indicators: 


\section{Methodological soundness}

This characteristic refers to the idea that the methodological basis for the production of indicators should be attained by following internationally accepted standards, guidelines, or good practices. This dimension is necessarily dataset-specific, reflecting different methodologies for different datasets. The elements referring to this characteristic are (i) concepts and definitions, (ii) scope, (iii) classification / sectorization, and (iv) basis for recording. Particularly important is the characteristic of accuracy and reliability, referring to the idea that indicators should be based upon data sources and statistical techniques that are regularly assessed and validated, inclusive of revision studies. This allows accuracy of estimates to be assessed. In this case accuracy is defined as the closeness between the estimated value and the unknown true population value but also between the observed individual value and the "true" individual value. This means that assessing the accuracy of an estimate involves analyzing the total error associated with the estimate: sampling error and measurement error.

2. Integrity

Integrity refers to the notion that indicator systems should be based on adherence to the principle of objectivity in the collection, compilation, and dissemination of data, statistics, and results. The characteristic includes institutional arrangements that ensure

(i) professionalism in statistical policies and practices,

(ii) transparency, and

(iii) ethical standards.

3. Serviceability

Comparability is a particular dimension of serviceability. It aims at measuring the impact of differences in applied concepts and measurement tools/procedures

- over time, referring to comparison of results, derived normally from the same statistical operation, at different times,

- between geographical areas, emphasizing the comparison between countries and/or regions in order to ascertain, for instance, the meaning of aggregated indicators at the chosen level,

- between domains. This is particularly delicate when involving subjective measurement (e.g. cultural dimensions).

4. Accessibility

Accessibility relates to the need to ensure

(i) clarity of presentations and documentations concerning data and metadata (with reference to information environment: data accompanied with appropriate illustrations, graphs, maps, and so on, with information on their quality, availability and - eventual - usage limitations)

(ii) impartiality of access

(iii) pertinence of data

(iv) prompt and knowledgeable support service and assistance to users

In other words, it refers also to the physical conditions in which users can obtain data: where to go, how to order, delivery time, clear pricing policy, convenient marketing conditions (copyright, etc.), availability of micro or macro data, various formats (paper, files, CD-ROM, Internet...), etc.

Prerequisites of quality 
Although it does not represent a dimension of quality in itself, prerequisites of quality refers to all those (institutional or not) preconditions and background conditions for quality of statistics allowing.

In other words, indicators construction is not simply a technical problem but should become part of a larger debate concerning how to construct indicators obtaining a larger legitimacy to be promoted. These prerequisites cover the following elements:

(i) legal and institutional environment, allowing

a. conceptual framework to be defined

b. coordination power within and across different institutions to be framed

c. data and resources to be available for statistical work

(ii) quality awareness informing statistical work.

\section{Indicators' benchmark}

The identification of the indicators should be accompanied by the identification of the benchmark for each indicator or the point to be monitored.

A benchmark serves as a reference point in determining the current situation or position relative to the stated objective. In this perspective, a benchmark establishes the point from which measurements can be made. Indicators identify what will be measured.

The reference point could be represented by specific best practices or by comparison of current performance with previous performance and desired norms.

Benchmarking is the systematic process, which is useful for monitoring and securing continual improvement. $\mathrm{tt}^{4}$ allows

- priorities to be established

- better practices to be defined

- impacts to be evaluated

- awareness amongst the stakeholders to be aroused

The benchmark value is not always easy to be identified and requires a consensus not easy to be reached.

\section{The interpretative and explanatory models}

The frame described by the indicators should be aimed at drawing information and allowing explanations. Explanations are important not only for understanding phenomena but also for planning eventual policy intervention.

The conceptual models previously classified can be used, even though, as pointed out, in a complex perspective, including different perspectives of observation.

For example, each conceptual model allows the level of subjective well-being to be explained. However, in order to have a comprehensive interpretation of subjective well-being, also the other models should be considered.

${ }^{4}$ Using benchmarks plays an important role in the ambit of a program development. Used in combination with the program objectives they provide the basis for program accountability. 
That means that, for example, the level of satisfaction expressed with reference to work condition should be read by evaluating at the same time different explanatory dimensions, e.g., contextual conditions and individual dispositions.

\section{The policy goals}

The previous stage is necessary in order to proceed with defining and planning policy actions. Actually, the decision-making level can define action/intervention proposals concerning the concepts (even if through different intensity) by taking into account that the taken decisions will influence all the ambits, even when no resolution is made on each of them. The policy proposal is expressed through aims which can be:

- Conceptual aims (goals) that represent broad statements concerning what has to be achieved or which is the problem to be faced. Usually goals are placed at different levels (local, national, international, etc.).

- Operative aims (objectives) that represent the instruments identified in order to attain the conceptual aims. Objectives can have different temporal prospects (monthly, four-monthly, annual, bi-annual, etc.)

- Planning aims (actions) that represent the specific activities identified to accomplish objective. They can include developments and infrastructural changes in policies, in institutions, in management instruments, etc.

Below, some goals adoptable for each concept:

"Quality of life" (individual level)

Improving objective living conditions

Increasing subjective wellbeing

"Economic and social cohesion" (community level)

- Strengthening informal ties

- Increasing the role of institutions in encouraging social and political participation

\section{"Sustainability" (environmental and time level)}

- Increasing and enhancing human capital (education, training, ...)

- Preserving natural capital

- Preserving/improving equal opportunity of different generations 


\begin{tabular}{|c|c|c|c|c|c|c|c|c|c|c|c|c|c|c|c|c|}
\hline \multicolumn{2}{|c|}{$\begin{array}{c}\text { CONCEPTS } \\
\downarrow\end{array}$} & \multirow[t]{2}{*}{$\begin{array}{c}\text { DIMENSIONS } \\
\downarrow\end{array}$} & \multirow[t]{2}{*}{$\begin{array}{c}\text { GOALS } \\
\downarrow\end{array}$} & \multicolumn{13}{|c|}{$\begin{array}{c}\text { LIFE DOMAINS (AMBITS) } \\
\downarrow\end{array}$} \\
\hline & & & & 1 & 2 & 3 & 4 & 5 & 6 & 7 & 8 & 9 & 10 & 11 & 12 & 13 \\
\hline \multirow{2}{*}{\multicolumn{2}{|c|}{ Quality of life }} & $\begin{array}{l}\text { Living } \\
\text { conditions }\end{array}$ & Improvement & & & & & & & & & & & & & \\
\hline & & $\begin{array}{l}\text { Subjective } \\
\text { wellbeing }\end{array}$ & Enhancement & & & & & & & & & & & & & \\
\hline \multirow{2}{*}{$\begin{array}{l}\text { Economic } \\
\text { and } \\
\text { social } \\
\text { cohesion }\end{array}$} & $\stackrel{M}{M}$ & $\begin{array}{l}\text { Disparities, } \\
\text { inequalities } \\
\text { and social } \\
\text { exclusion }\end{array}$ & $\begin{array}{l}\text { Promotion of } \\
\text { equal } \\
\text { opportunities }\end{array}$ & & & & & & & & & & & & & \\
\hline & $\overrightarrow{\theta^{\prime}}$ & $\begin{array}{l}\text { Social } \\
\text { relations and } \\
\text { ties (social } \\
\text { capital) }\end{array}$ & $\begin{array}{l}\text { Strengthening } \\
\text { informal ties }\end{array}$ & & & & & & & & & & & & & \\
\hline \multirow{2}{*}{\multicolumn{2}{|c|}{ Sustainability }} & $\begin{array}{l}\text { Human } \\
\text { capital }\end{array}$ & Enhancement & & & & & & & & & & & & & \\
\hline & & $\begin{array}{l}\text { Natural } \\
\text { capital }\end{array}$ & Preservation & & & & & & & & & & & & & \\
\hline
\end{tabular}

\begin{tabular}{|l|l|l|l|l|l|l|l|l|l|l|l|l|}
\hline $\begin{array}{l}\text { Socio- } \\
\text { economic } \\
\text { structure }\end{array}$ & $\begin{array}{l}\text { Demographic and socio- } \\
\text { economic structures }\end{array}$ & Values and attitudes & Changes & & & & & & & & \\
\cline { 2 - 9 }
\end{tabular}

It is important to set clear and shared goals (in the wellbeing for all perspective), by giving philosophical and political debate (understandable for all) more space.

After goals, objectives and actions have been defined, concrete and observable elements allow the process to be assessed. Consequently, for each dimension, different levels of evaluation can be defined. By exemplifying the process through the two dimensions of the quality-of-life concept, the combination of the two dimensions leads to the following well-known evaluating taxonomy (Zapf, 1975, 1984):

\begin{tabular}{|c|c|c|c|}
\hline & & \multicolumn{2}{|c|}{ Subjective wellbeing } \\
\hline & $\begin{array}{c}\text { Level } \\
\downarrow\end{array}$ & High & low \\
\hline \multirow{2}{*}{ Living conditions } & 5. high & 1. well-being & 2. dissonance \\
\hline & low & 3. adaptation & 4. deprivation \\
\hline
\end{tabular}

\section{Managing indicators: instructions for use}

Monitoring wellbeing through indicators puts some issues representing at the same time a challenge (given by the complexity), a risk (given by the over-reductionism) and a need (represented by the relativization).

The key allowing the proper identification of new measures lies in the players' (statisticians, researchers, analysts, policy makers, and so on) capacity and awareness in considering the complexity, avoiding 
over-reductionism and investigating relativization.

Complexity

Changing paradigm introduces several methodological implications in identifying and observing indicators:

- levels of observation, which can be (individuals, groups), and macro (communities, regions, countries, etc.): macro does not correspond necessarily to sum of micros and micro does not necessarily reflects what emerges at macro level;

- times of observation, which will not be necessarily equal for all selected indicators according with their different dynamics; in fact, some phenomena show "fast" dynamics while others show extended changing progression;

- objective and subjective levels, which represent two aspects of the reality integrating each other;

- internal level and external level, duality sensitive to individual observation; in fact, at individual level the defined concepts should be observed at both "external" (e.g., objective living conditions, equity and sustainability of those conditions) and "internal" (e.g., subjective evaluations about the living conditions, subjective perceptions about equity and sustainability of living conditions) level;

- classifying indicators in terms of input and outcomes aspects is difficult to accomplish; in fact, some aspects could be classified at the same time (or in subsequent times) as input or output; families' lower expenses for foodstuffs could represent an output indicator related to a short-term situation but could represent also an input indicator towards a change (worsening?) in family members' health status;

- the transition from quantity to quality paradigm ${ }^{5}$ implies a consistent choice of the indicators, this means, for example, turning an indicator of quantity like "life expectancy" to an indicator of quality like "healthy life expectancy".

\section{Making relative}

The indicators selection implies a reflection about objectives of their adoption (monitoring, comparing and benchmarking among territories, supporting and evaluating policy decisions, ...)

In particular, that reflection requires considering two related indicators' characteristics: consistency with reference to concepts and adequacy with reference to the territory (country, region, province, ...).

Wellbeing definition, for example, finds a wide agreement (integration between living conditions and subjective wellbeing). Its operationalization (in terms of indicators) should take into account the definition's declension in the territorial ambit in which the observation is made. Consequently, different areas could adopt different indicators in order to measure the same concept.

This could introduce problems in the process of comparing different areas, by taking into account that they will be compared with reference to the concept not with reference to single indicators (comparing synthetic indicators).

Relativization involves also the wellbeing concept to measure and monitor and should urge better policies. Let's show a simple and simplified example: how to interpret a region's high value produced by the ratio number of hospital bed / dimension of population? At a first glance, a high level

\footnotetext{
${ }^{5}$ The dichotomy quality/quantity introduced here refers to the technical expression of indicators and not to their meaning.
} 
could reveal a region paying attention to needs and requirements of population's health. A later look could be alarming: does the high number of available hospital beds fit a real need of that territory? In so, the interpretation could lead to particular evaluation of policy decisions. The territory's need, for example, could be related to particular pathologies: the policy action could have been directed towards other domains (e.g., environment). So, proposing city mobility compatible with a healthy environment allows air quality and life style to be improved allowing a healthy life and hopefully a lower need of hospital beds.

\section{Reductionism}

Reductionism can not be avoided, since it is actually impossible pull an image and a story from a pure observation of the reality and completely stackable on it.

On the other side, it is dangerous concentrating just on few elements and statistically inferring from them the sufficiency of the reduced observation.

In fact, statistically a high correlation between two indicators does not authorize to do without one among them. Such kind of decision implies the notion according which indicators showing high correlation are actually measuring the same concept's component.

The range of such kind of decisions is in the reality: the relationship between two indicators (e.g., number of firemen and amount of damages in a fire) can be high but mediated by a third one (e.g., dimension of the fire). If the third indicator's nature changes, the relationship between the two others changes or disappears, even though they will continue to describe, autonomously, the reality. If, by observing the previous high correlation, we excluded of the two indicators, doing without one of them could deny ourselves precious pieces of the whole picture (as represented by the indicators).

This means that having a solid conceptual model allowing indicators concepts' relationships to be identified and interpreted

From the technical point of view, reductionism refers to the possibility of synthesizing the collected information.

The systematic identification of elementary indicators, identified in terms of concepts and domains, allows a downright "system of indicators" to be constructed (more complex than a simple "set of indicators", which are not always related to a conceptual framework).

In some cases, it will be necessary to define syntheses. The synthesis concerns different aspects of the system (Maggino, 2009) and needs analytical procedures to be defined.

(i) Synthesis of basic indicators at micro level. This synthesis requires synthesising elementary indicators by creating synthetic scores. In case of subjective indicators, this synthesis has been widely and deeply studies and found strengthened analytical techniques (coming from the psychometric statistics) along with other advanced techniques based upon discrete mathematics. Each synthetic score involves indicators referring to only one conceptual dimension (in other words, the indicators are conceptually and statistically homogeneous);

(ii) Aggregating units (cases, subjects, ...). This aggregation aims at mainly comparing macro units (social groups, age groups, geographic areas), with reference to [synthetic or not] indicators, as defined in the monitoring perspectives. This kind of synthesis is generally accomplished by applying statistical instruments (e.g., average), very simple even though 
unsatisfying since they do not allow the phenomenon's distribution to be correctly represented and synthesized. A possible (not necessarily the best) solution is to report, for example, the percentage of a subgroup or an dispersion index (standard deviation or interquartile range);

(iii) Synthesis at macro level. This aggregation aims at creating complex indicators allowing the complexity to be managed. By drawing again the previous table, we can identify different syntheses:

- "by raw" (R), when synthesis concerns each [multidimensional] concept (e.g. "subjective wellbeing")

"by column" (C), when synthesis concerns each ambit/domain. This kind of aggregation, referring to different concepts) is little recommendable since the score eventually produced are not interpretable

- "by sub-column" (RC), when the synthesis concerns one concept (or dimension) and one single ambit/domain. This kind of aggregation produces a meaningful and interpretable measure.

The obtained matrix is represented in Annex B.

Subsequent "higher level" syntheses could lead to the construction of super-indicators, difficult to be interpret.

1. Towards the fulfilment of a good society: what is needed?

Dealing with societal wellbeing by taking into account its multidimensionality not only involves philosophical/political issues but concerns each individual's and community's real life. In other words, dealing with individuals' and communities' real life means discussing by taking into account the three concepts, which should be considered together.

Consequently, the three concepts should be taken into account at both individual and community level. The family's decision to have or not a vacation or the community's decision to have or not a new tram line should take into account issues related to quality of life, cohesion and sustainability.

The different levels (individual, family, local, national ...) interact and lead to fruitful and positive changes only if the decision-making process is supported be a monitoring system, seen as a continuous observation of the societal well-being allowing changes to be observed, effects of policies to be evaluated, and future activities to be planned.

However, the monitoring should be grounded on:

a solid democratic system

a transparent media system

education of citizens

In this, important roles are played by the education and research system (school, university, ...) and the official statistics, two strategic and institutional sectors, both meeting social consensus.

Are indicators enough?

As said, a complex approach is needed in order to measure and monitor societal wellbeing. Complexity requires many indicators, designed and organized in consistent conceptual structure. 
The obtained system provides all the cognitive instruments allowing decisions to be taken more consciously. In any case, those decisions appertain to policy. In this frame, we could image the policy maker like a pilot sitting at the flight desk (Maggino, 2009).

Statistics have the task of defining, constructing and developing the instruments located in the cockpit.

However, that activity needs:

\section{a clear definition of destination (àgoals)}

a democratic process allowing the community to take a shared decision concerning destination (à democracy)

a deep knowledge of pre-conditions (à resources, ...)

a constant monitoring of flight conditions (à monitoring)

a continuous transmission and sharing of information on flight conditions (à communication and information system)

a cultural environment available to support scientific research (basic and applied) to improve the whole system's conditions

a system allowing the community to face and manage emergencies (à welfare and social security, ...)

If even just one of these items is missed, achieving a good society is seriously damaged.

\section{References}

Berger-Schmitt R. and H.-H. Noll (2000) Conceptual Framework and Structure of a European System of Social Indicators, EuReporting Working Paper No. 9, Centre for Survey Research and Methodology (ZUMA) - Social Indicators Department, Mannheim.

Diener E., E. Suh (1997) Measuring quality of life: economic, social, and subjective indicators, Social Indicators Research, vol. 40, pp. 189-216.

Eurostat (2000) Definition of quality in statistics and Standard quality report, Eurostat.

Felce D., Perry J. (1995). Quality of Life: Its Definition and Measurement. Research in Developmental Disabilities, 16 (1), pp. 51-74

Horn R.V., (1993) Statistical Indicators, Cambridge University Press, Cambridge.

Johansson S. (2002). Conceptualizing and Measuring Quality of Life for National Policy. Social Indicators Research, 58, pp. 13-32.

Maggino F. (2009) The state of the art in indicators construction in the perspective of a comprehensive approach in measuring well-being of societies, Firenze University Press, Archivio E-Prints, Firenze.

Maggino F. e E. Ruviglioni (2011) Preaching to the Choir: Are the Commission's Recommendations 
Already Applied?. Social Indicators Research, Vol. 102, Issue 1, pp. 131-156.

Nuvolati G. (1997). Uno specifico settore di applicazione degli indicatori sociali: La qualità della vita. In: Zajczyk F. II mondo degli indicatori sociali, una guida alla ricerca sulla qualità della vita. La Nuova Italia Scientifica, Roma, pp. 69-94.

Patel S., M. Hiraga, and L. Wang (World Bank) D. Drew and D. Lynd (Unesco) (2003) A Framework for Assessing the Quality of Education Statistics, World Bank - Development Data Group and UNESCO - Institute for Statistics.

Sirgy M.J. (2011) Theoretical Perspectives Guiding QoL Indicators Project, Social Indicators Research, vol. 103, pp.1-22.

Sirgy M.J., A.C. Michalos, A.L. Ferriss, R.A. Easterlin, D. Patrick and W. Pavot (2006) The Qualityof-Life (QOL) Research Movement: Past, Present, and Future, Social Indicators Research, vol. 76, n.3, pp. 343-466.

Stiglitz J. E., A. Sen \& J.-P. Fitoussi eds (2009) Report by the Commission on the Measurement of Economic Performance and Social Progress, Paris. http://www.stiglitz-sen-fitoussi.fr/en/index.htm

Zapf W. (1975) Le système d'indicateurs sociaux: approches et problèmes, Revue Internationale des Sciences Sociales, Vol. XXVII, n. 3.

Zapf W. (1984) Individuelle Wohlfahrt: Lebensbedingungen und Wahrgenommene Lebensqualität, in W. Glatzer e Zapf W. (eds.) Lebensqualität in der Bundesrepublik, Frankfurt a. M. - New York, Campus, pp. 13-26. 